\title{
ANALISIS PENDEKATAN STUDI TEKNOLOGI E-BISNIS STUDI KASUS “GO-JEK”
}

\author{
Erniza Dwi Wahyuni \\ $185100042 P$
}

Fakultas Komputer

Ernizadwiwahyuni.student@umitra.ac.id

\begin{abstract}
Abstrak
Semakin tingginya tuntutan mobilitas masyarakat, tentunya membutuhkan sarana transportasi yang dapat memberikan pergerakan dan perpindahan dari satu tempat ke tempat yang lain dengan cepat, walaupun jarak tempuhnya jauh. Adanya terobosan transportasi berbasis aplikasi online GO-JEK yang menggabungkan jasa transportasi dengan teknologi komunikasi di dunia transportasi Indonesia, membuat masyarakat harus menentukan transportasi mana yang paling cocok dengan kebutuhannya untuk melakukan mobilitas.

Studi ini memfokuskan pada tindakan sosial yang dilakukan masyarakat dalam menggunakan sarana transportasi. Bagaimana tindakan sosial yang dilakukan masyarakat yang menggunakan GO-JEK sebagai sarana transportasi .Pengumpulan data dalam penelitian ini adalah wawancara mendalam dan observasi tidak langsung.

Hasil yang ditemukan dalam penelitian ini antara lain : 1) Transportasi berbasis aplikasi online, juga menyediakan jasa layanan memesan makanan, pengantaran barang dan belanja yang dapat dimanfaatkan oleh ibu-ibu rumah tangga ataupun wirausaha rumahan.
\end{abstract}

Kata kunci: transportasi berbasis aplikasi online, pengguna GO-JEK 
A. PENDAHULUAN

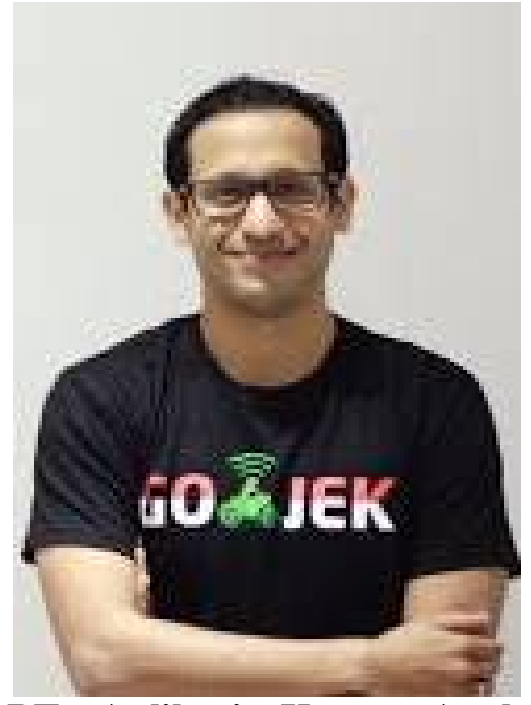

PT Aplikasi Karya Anak

Bangsa atau yang lebih dikenal dengan GO-JEK merupakan sebuah perusahaan teknologi asal Indonesia yang

melayani angkutan melalui

jasa ojek. Perusahaan ini didirikan pada tahun 2010 di Jakarta oleh Nad iem Makarim warga negara Indonesia lulusan Mast er of Business Administration dari Harvard Business School. Ide mendirikan GO-JEK muncul dari pengalaman pribadi Nadiem Makarim menggunakan transportasi ojek hampir setiap hari ke tempat kerjanya untuk menembus kemacetan di Jakarta. Saat itu, Nadiem masih bekerja sebagai Co-Founder dan Managing Editor Zalora Indonesia dan
Chief Innovation Officer Kartuku.

Saat ini, GO-JEK telah tersedia di 50 kota di Indonesia. Saat ini juga ada untuk iOS, di App Store. Gojek Juga menyediakan layanan pembayaran digital yaitu Gopay, Layanan Go Jek juga memenuhi kebutuhan setiap hari, Saat ini GO-JEK sedang Terus melakukan Ekspansi ke Negara - Negara di Asia Tenggara, dan kini sudah ada di Thailand dan Vietnam kabar nya GO-JEK akan merilis di Singapura dan Flipina selanj utnya.

\section{B. PEMBAHASAN / STUDI} KASUS

Penggunaaan GO-JEK oleh masyarakat, dapat diduga karena kekecewaan yang muncul akibat dari lemahnya fasilitas transportasi massal yang ada. Perlu diketahui, terdapat persoalan yang tidak bisa lepas dari transportasi massal, antara lain adalah; tidak adanya jadwal yang tetap, pola rute yang memaksa pengguna harus transfer atau oper, penumpang yang berlebih saat jam sibuk, kondisi internal dan eksternal yang buruk, dan cara mengemudikan kendaraan yang sembarangan dan membahayakan keselamatan. Kelemahan-kelemahan transportasi publik di Indonesia 
dapat disebabkan karena sistem penyelenggaraannya yang mulai kurang diperhatikan. Dapat dilihat pada pengelolaan angkutan kota di seluruh dunia, pada dasarnya terdapat dua jenis, yaitu: dikelola oleh pemerintah (publik), dan dikelola oleh pihak swasta. Angkutan kota di Negara maju biasanya dikelola oleh perusahaan milik pemda ataupun kontrak dengan operator, sedangkan di Negara berkembang diserahkan pada pihak swasta. Berdasarkan permasalahan akan kelemahan transportasi massal yang telah dijelaskan membuat masyarakat harus menentukan pilihan melalui berbagai alternatif dalam memilih dan menggunakan transportasi guna menghindari berbagai resiko yang akan dihadapi kedepannya. Hal ini dimungkinkan, karena GOJEK dapat dijadikan alternatif dalam upaya mengatasi resiko yang dialami masyarakat akibat kelemahan sistem transportasi massal, serta kemacetan yang sering terjadi di jalanan. Masyarakat banyak terbantu semenjak hadirnya GO-JEK karena dimudahkan dengan berbagai menu layanannya dan promosi yang dapat menarik konsumen. Pada awal hadirnya GO-JEK di Indonesia hanya terdapat layanan Go-Ride, GoFood, Go-Mart, Go-Send, dan Go-Box namun, GO-JEK semakin menyesuaikan dengan kebutuhan masyarakat, sehingga menambahkan menu layanan baru seperti Go-Car, Go-Clean, Go-Massage, GoGlam, Go-Tix, Go-Auto, GoMed, dan Go-Pulsa

\section{ID SECURITY}

QWTD4452377-ASP-5244107

\section{KESIMPULAN}

Kehadiran sarana transportasi berbasis aplikasi online, seperti GO-JEK di Indonesia membuat masyarakat merasa bahwa kebutuhan untuk mobilitas selain menggunakan sarana transportasi tradisional, sangatlah penting. Kehadiran GO-JEK mengundang perhatian masyarakat untuk mengetahui lebih jauh mengenai transportasi online ini. Semenjak kehadirannya, mulai dari melakukan pemasaran dan penyebaran secara besarbesaran, baik melalui media televisi, media massa maupun media cetak memudahkan masyarakat mengetahui informasi mengenai transportasi berbasis aplikasi online. Transportasi berbasis aplikasi online, adalah layanan jasa transportasi yang dapat diakses secara online melalui smartphone. Kemunculan GO-JEK, membuat masyarakat bertanyatanya dan mencari tahu keunggulan-keunggulan apa saja yang ada, jika menggunakan transportasi online ini. Tak hanya itu, masyarakat juga mengetahui 
GO-JEK secara langsung ketika berada di jalan raya.

\section{E. DISKUSI}

Saya bersama teman saya bernama Arnando mendiskusikan tentang contoh ini dengan sangat baik Hasil diskusi dari materi ini adalah menurut Arnando GO-JEK adalah sebuah sarana yang memudahkan kita dalam berbagai hal, terutama dizaman modern yang kebanyakan masyarakat menggunakan aplikasi smartphone sebagai alat bantu dalam berinteraksi sehari-hari. GO-JEK di terapkan sebagai aplikasi yang bisa di download di play store, disini GO-JEK tidak hanya berfungsi sebagai transportasi tapi banyak hal yang bisa kita gunakan dalam aplikasi ini untuk memudahkan kita dalam kehidupan terutama untuk orang ang super sibuk. Dalam aplikasi GO-JEK kita dapat memesan makanan, membayar token listrik, mengisi pulsa tanpa harus keluar rumah dan bolak balik tentu. Jadi dengan adanya GO-JEK ini adalah sebuah kemajuan teknologi yang luar biasa dengan fiturfitur dan saran yang ditawarkan, karna aplikasi ini kita dalam kehidupan seharihari dapat terbantu dan dipermudah dalam menjalani aktifitas kehidupan.

\section{F. REFERENCE}

[1] O. M. Febriani and A. S. Putra, "Sistem Informasi Monitoring Inventori Barang Pada Balai Riset Standardisasi Industri Bandar Lampung," J. Inform., vol. 13, no. 1, pp. 90-98, 2014.

[2] A. S. Putra, "Paperplain: Execution Fundamental Create Application With Borland Delphi 7.0 University Of Mitra Indonesia," 2018.

[3] A. S. Putra, "2018 Artikel Struktur Data, Audit Dan Jaringan Komputer," 2018.

[4] A. S. Putra, "ALIAS MANAGER USED IN DATABASE DESKTOP STUDI CASE DB DEMOS."

[5] A. S. Putra, "COMPREHENSIVE SET OF PROFESSIONAL FOR DISTRIBUTE COMPUTING."

[6] A. S. Putra, "DATA ORIENTED RECOGNITION IN BORLAND DELPHI 7.0."

[7] A. S. Putra, "EMBARCADERO DELPHI XE 2 IN GPUPOWERED FIREMONKEY APPLICATION."

[8] A. S. Putra, "HAK ATAS KEKAYAAN INTELEKTUAL DALAM DUNIA TEKNOLOGY BERBASIS REVOLUSI INDUSTRI 4.0."

[9] A. S. Putra, "IMPLEMENTASI PERATURAN PERUNDANGAN UU. NO 31 TAHUN 2000 TENTANG DESAIN INDUSTRI BERBASIS INFORMATION TECHNOLOGY."

[10] A. S. Putra, "IMPLEMENTATION OF PARADOX DBASE."

[11] A. S. Putra, 
"IMPLEMENTATION OF

TRADE SECRET CASE STUDY SAMSUNG MOBILE PHONE."

A. S. Putra,

"IMPLEMENTATION

PATENT FOR APPLICATION

WEB BASED CASE STUDI

WWW. PUBLIKLAMPUNG.

COM."

[13] A

"IMPLEMENTATION

SYSTEM FIRST TO INVENT

IN DIGITALLY INDUSTRY."

[14] A. S. Putra, "MANUAL REPORT \& INTEGRATED DEVELOPMENT

ENVIRONMENT BORLAND DELPHI 7.0."

[15] A. S. Putra, "PATENT AS RELEVAN SUPPORT RESEARCH."

[16] A. S. Putra, "PATENT FOR RESEARCH STUDY CASE OF APPLE. Inc."

[17] A. S. Putra, "PATENT PROTECTION FOR APPLICATION INVENT."

[18] A. S. Putra, "QUICK REPORT IN PROPERTY PROGRAMMING."

[19] A. S. Putra, "REVIEW CIRCUIT LAYOUT COMPONENT

REQUIREMENT ON ASUS NOTEBOOK."

[20] A. S. Putra, "REVIEW TRADEMARK PATENT FOR INDUSTRIAL TECHNOLOGY BASED 4.0."

[21] A. S. Putra, "TOOLBAR COMPONENT PALLETTE IN OBJECT ORIENTED PROGRAMMING."

[22] A. S. Putra, "WORKING
DIRECTORY SET FOR PARADOX 7."

[23] A. S. Putra, "ZQUERY CONNECTION

IMPLEMENTED

PROGRAMMING STUDI

CASE PT. BANK BCA Tbk."

[24] A. S. Putra, D. R. Aryanti, and I. Hartati, "Metode SAW (Simple Additive Weighting) sebagai Sistem Pendukung Keputusan Guru Berprestasi (Studi Kasus: SMK Global Surya)," in Prosiding Seminar Nasional Darmajaya, 2018, vol. 1, no. 1, pp. 85-97.

[25] A. S. Putra and O. M. Febriani, "Knowledge Management Online Application in PDAM Lampung Province," in Prosiding International conference on Information Technology and Business (ICITB), 2018, pp. 181-187.

[26] A. S. Putra, O. M. Febriani, and B. Bachry, "Implementasi Genetic Fuzzy System Untuk Mengidentifikasi Hasil Curian Kendaraan Bermotor Di Polda Lampung," SIMADA (Jurnal Sist. Inf. dan Manaj. Basis Data), vol. 1, no. 1, pp. 21-30, 2018.

[27] A. S. Putra, H. Sukri, and K. Zuhri, "Sistem Monitoring Realtime Jaringan Irigasi Desa (JIDES) Dengan Konsep Jaringan Sensor Nirkabel," IJEIS (Indonesian J. Electron. Instrum. Syst., vol. 8, no. 2, pp. 221-232.

[28] D. P. Sari, O. M. Febriani, and A. S. Putra, "Perancangan Sistem Informasi SDM Berprestasi pada SD Global 
Surya," in Prosiding Seminar Nasional Darmajaya, 2018, vol. 1, no. 1, pp. 289-294. 